\title{
Javanese Language and Culture in the Expression of Kebo Bule in Surakarta: An Ethnolinguistic Study
}

\author{
Wakit Abdullah $1 \bowtie$ \\ ${ }^{1}$ Universitas Negeri Sebelas Maret, Indonesia
}

DOI: http://dx.doi.org/10.15294/komunitas.v8i2.7195

Received : 5 September 2015 ; Accepted: 8 August 2016; Published: 30 September 2016

\begin{abstract}
The phenomenon of Kebo Bule as the actuality of Javanese language and culture in Surakarta can be criticized from the perspective of ethnolinguistic. In terms of the descriptive qualitative expression of the language and culture of Java, Kebo Bule from the perspective of Ethnolinguistic is identifiable on the background of it in Surakarta, the influence of Kebo Bule to the Surakarta's Court, and the meaning of Kebo Bule as one of the magical icons of the Surakarta's Court. Ethnolinguistic as a theoretical concept is part of the branch of linguistic studies that seeks to study the language understanding in a broader context in order to express an understanding of the culture. Methodologically, understanding the relationship between the expression of language and culture in Kebo Bule can be peeled using ethnomethodology to ethnolinguistics by utilizing ethnoscience (knowledge typically owned by ethnicity, tribe, people) to find the cultural themes of people related to their mindset and the worldview. The research data encompasses of oral and written data, verbal data sources from informants and writes from a library. The validation of the data was done by triangulation, and data analysis used ethnoscience (especially taxonomic, domain and componential analysis). Results of the discussion is presented in the form of narrative texts related to the background, the effect and meaning of Kebo Bule for the existence of the language and culture of Java in Surakarta.
\end{abstract}

Keywords: ethnolinguistics; Kebo Bule; month of Sura; Surakarta

\section{INTRODUCTION}

The existence of Kebo Bule (literally brunette buffalo) has long been a phenomenal problem in the tradition of Javanese language and culture, especially in Surakarta. Its phenomenality can be identified from the verbal and nonverbal expressions. Verbal expression of Kebo Bule is identified from the language, while the nonverbal one is identified from the historical, cultural, spiritual, practical and political aspects. Verbally, why Kebo Bule is also expressed with a term Kebo Slamet", "Kyai Slamet" which is linked to the tradition of ritual ceremony on the evening of first month of Sura. Nonverbal aspect of Kebo Bule can be identified from the historical, cultural, spiritual, practical and political aspects.
Historically, up to now the information about Kebo Bule seems to remain unclear, there was only lack of sufficient evidence, although many studies have been done in the areas alike. Information about the Kebo Bule tends to be likely found in oral stories without evidence that reinforces the figure of Kebo Bule as "the Sacred Kebo", "the Heirloom Kebo", "the Blessing Kebo", in contrary just being speared by an ignorant buffalo dead. Some literature sources and oral information are obtained from the communities living in Surakarta. Having done deep interview with the informants, the information remains uncertain, one to another implies different correspondence, instead it last with conflicting, making the object seems to remain less convincing. At

(C) 2016 Semarang State University. All rights reserved p-ISSN 2086 - 5465 | e-ISSN 2460-7320

Corresponding author :

Address: Faculty of Cultural Sciences

J1. Diponegoro, D.228, RT.08/RW.XVI Josroyo

Indah Jaten Karangnyar (57771)

Email : abdullahwakit@yahoo.com

UNNES JDURNRLS 
the end, the society can only understand and follow that tradition uncritically as a source of meaningful life. Some related sources of Kebo Bule were derived from the informants in the form of oral stories (folklore) and written source comes from the news media (books, magazines, newspapers, and internet) and serat babad. In this case, serat babad as written sources tells the "history", but the writer's subjectivity affect the story and fill in the account, because of the motivation customized with background, insightful writer and writing targets.

The oral source comes from informants, both relatives of the palace and the writers who tries to uncover matters related to the figure of Kebo Bule. The validity of the data is also inadequately deemed to be scientific. The written sources related to the history of Kebo Bule in Surakarta has been mentioned in the Babad Sala (Chronicle of Sala). In the babad it is mentioned that the ancestors of Kebo Bule is the dearest buffalo (klangenan) to Pakubuwono II on enthroning at The Court of Kartasura. After moving to Surakarta, Kebo Bule remains the dearest animal ${ }^{1}$ which is considered possessing magical value related to the existence of lives in the Surakarta's Court, both physically and mentally. There is an explanation that Kebo Bule was originally a gift from the Duke of Ponorogo to Sunan Pakubuwana II, but nobody mentioned that Kebo Bule's offspring was the cattle of Kanjeng Sultan Agung Hanyakrakusuma of Mataram. This means that are there significant differences and time inequalities? (Sultan Agung Mataram Hanyakrakusuma's reign, p.1613-1642; whereas Sri Susuhunan Pakubuwono II reigned, p.1711-1749). From various obtained sources historically related to figure and expression, the scientific valid data of Kebo Bule in Surakarta is less assuring. Therefore, in this paper too, there are aspects need to be criticized further for unclear and incomplete things, since the validity of the data remains difficult to trace the truth to account reviews scientifically.

\section{LITERATURE}

The term "meaning" according to Kridalak- sana (1993) refers to a speaker's intention; the influence of language units in perception or understanding of human behavior or human groups. The cultural significance (cultural meaning) by Subroto (2011) refers to the meaning of a language in relation to the cultural context of society. Correspondingly, Mahsun (2005, p.81; Childs and Mallinson 2006; Kim et al. 2008; Levisen 2015) mentioned many ways to uncover the cultural behavior of people; one of them is with the use of language. Sapir-Whorf (in Clark and Clark 1977) stated that language has a significant influence on the way people think. In other words, the way people looked at the meaning of life is recorded in the structure of the language.

According to Dove (1985, p.15), the role of traditional culture is closely linked with the social, economic and ecological processes of society. Koentjaraningrat (1990, p.183184 \& 224) stated that culture encompasses complexities including ideas, norms, values, rules, complex patterned activity and actions of men in society and objects of human work. Practically speaking, tradition in a society is based on views of life, personal and environment or society (Geertz 1981; Mulder 1985; Koentjaraningrat 1984; Liebkind 2010; Majid and Levinson 2011). The Javanese people's way of life reflects the belief on both the cosmo-mythical and cosmomagical assumptions in which the surrounding nature provides a powerful, influential, material and spiritual life of society (Mulder 1984; Thorne and Payne 2005), and depends also on each other of the individual (Sunobroto 1983; Medubi 2010; Perales 2005; Tanaamah and Wenas 2014). Boas (in Ihromi 1999) stated that cultural traits must be studied in the context of the society in which it arises. In this case, it is the ethnolinguistic that peels relations of the Javanese language and culture (the Javanese traits) in viewing Kebo Bule in Surakarta.

Mindset or literal mindset of a society (Ahimsa 1997; Fernandez 2009) is a public knowledge (cognition), among which are classifications, rules, and principles were expressed through language. Language may record the state of ecological environment 
in the vicinity. Therefore, the language too could imply various names or terms that indicate the object (noun) or work (verb) or nature (adjective) that exist around the human's lives. As an illustration, the Javanese acknowledged Kebo Bule as thing associated with the existence of the Court of Surakarta. It was as summarized in the figure of the buffalo cattle coincidently found in a "Caucasian colored one" and was gradually perceived to possessing a supernatural power and other different perceptions deeming it as the unusual or weird buffalo (PC. Pitana, August 20, 2016).

In this case, the phenomenon of Kebo Bule as an expression of cultural recount in the language of Java at the night of $1^{\text {st }}$ Sura can be criticized on its existence associated with the relationship of language and culture of Java. Thus, language is a system of symbol and sound which the people use to give birth into thoughts and feelings (Poerwadarminta 1982). Language is related to culture which is studied ethnolinguistically. The ethnolinguistic according to Foley (1997) is a branch of linguistics concerned with the position of language in a social and cultural context to promote and defend the cultural practices and social structures. In this case, the ethnolinguistic study utilizes the ethnoscience or the new ethnography or cognitive anthropology as its perspective underpinnings (Spradley 1997). Methodologically, it is deemed to be sufficient to reveal aspects of human knowledge that guide everyday behavior. Ethnoscience emphasizes on knowledge of a system or device which is typical of a society or knowledge that shows the group surviving in a particular ecological niche. Definitively, the ethnoscience reflects a more precisely sense of indigenous knowledge, tribe or a particular social group (Ahimsa-Putra 2003). Ethnoscience related to the knowledge of the language is the easiest way to come to the knowledge of a community system. Good knowledge of language through a hidden (tacit) and unhidden (explicit) variety are resolvable by researchers (Ahimsa 1985).

Previous studies discussing about local thought associated with Kebo Bule among them are Andrik Purwasito (2008) on "Kebo Bule in The Court of Surakarta: Kebo Bule is the Wizard" that explains the cultural aspect, didactic, spiritual and practical culture in the court of Surakarta as reflected in Kebo Bule and the public assumption. This study has not yet discussed explicitly from the ethnolinguistic perspective. Toto (2009) on Kebo Bule mentioned that Kebo Bule has a symbolic, practical, cultural, and spiritual function (Toto, November 14, 2014). Then as described by Yosodipuro (August 10, 2015), the ancestor of this typical colored buffalo (called bule 'white slightly reddish') was a gift from the Duke of Ponorogo to Pakubowono II, which is applied as cucuk lampah (guardian) of a heritage palace named Kyai Slamet. To this day, the court of Surakarta has never been willing to explain what form of inheritance called "Kyai Slamet" (whether the information was exist or not remains unclear) (PC. Puger, 21 August, 2016).

"The buffalo (Kebo Bule) existed from the era of Kartasura, PB 2 I think there were two of them, they were the buffalo of pisungsung (gift) from the Duke of Ponorogo who sent them as a gift, [further information] this buffalo remains unclear of somewhere".

Meanwhile, Raden Mas Said (Kasunanan Surakarta Hadiningrat, August 19, 2016) in the Babad Sala told that Kebo Bule is an animal of klangenan 'the dearest cattle' of Sunan Pakubuwana II in the Court of Kartasura up to the Court of Surakarta. Nearly all the writers could eventually report that Kebo Bule was descended from the buffalo at the time of Sri Susuhunan Pakubuwono II (1711-1749). It is said that this albino buffalo origin is a gift from the Duke of Ponorogo, as the guardian of the grand prize, which is a heritage that was named Slamet and then was associated with a name Kebo Slamet (the salvation buffalo). Because its body is well-shaped, handsome and unique colored -skin, albino buffalo has become cattle (Independenpos.com, October 26, 2014). "The sacredness of Kebo Slamet (Kebo Bule) in the Court of Surakarta" among other things contains an explanation of the uniqueness and magic sides of "Kebo Slamet" in the Ja- 
vanese community's tradition and spiritual, especially at the eve of $1^{\text {st }}$ Month of Sura around the neighborhood of the Court of Surakarta (Miksic 2004, p.93)."Kyai Slamet: Abdi Setia Sultan Agung "explains the closeness of Kyai Slamet with "Kebo Bule" which eventually led to the naming of the buffalo as" Kyai Slamet" (Miksic 2004, p.93). As Kebo Bule by Sunan Pakubuwana II was named Kyai Slamet, it also described the Kyai Slamet's tomb located in one fence to the tomb of Kyai Mlati, located at the back side of the tomb next to the king of Mataram's graveyard in Wonogiri, precisely on the back side-south or behind the complex tombs of the kings of Surakarta.

\section{RESEARCH METHODS}

This research used ethnometodology to ethnolinguistic, especially ethnography (Spradley 1997) and linguistic methods (Subroto 1992; Sudaryanto 1993). The ethnolinguistic method utilized the ethnoscience methodology with 12-step groove advanced research stages (Spradley 1997) to identify the language and culture of Java summarized in Kebo Bule. The research data is in the form of qualitative data: verbal data (terms, words, phrases, clauses, discourse), the nonverbal data (cultural events, cultural expression) and practical data (cultural events: preparing the offerings, the offerings, the day of $1^{\text {st }}$ month of Sura). The primary data of this research were (a) oral data in the forms of verbal and written data sources concerning the story and history of Caucasian buffalo (Kebo Bule) (b) sources of information obtained from selected informants. The secondary data sources obtained from important notes, articles, books, and previous research reports. The data collection techniques employed participant observation (Spradley 1980, p.107, 124, 128). The data collection techniques involved participant observation, in-depth interviewing documents and libraries analysis, if possible. To be able to get subsequent information from informants, this study applied purposive sampling model of snowball sampling (Sutopo, 2006). The validity of data was tested by using the sources criticism (external and internal) (Koentjaraningrat 1977, p.79-84), and triangulation (including the sources, methods, theory, researchers) (Moleong 1989, p.112; Sutopo 1986, p.70-74). Qualitative data analysis is by utilizing ethnoscience especially taxonomic analysis, domain analysis and componential analysis to find themes of culture. The results are presented in a narrative text in the form of interactive analysis undergoing the cycle process (Sutopo 2006).

\section{DISCUSSION}

Based on the description of the research data, the discussion in this study includes the background of the Kebo Bule in Surakarta, the influence of Kebo Bule on The Court of Surakarta, and the meaning of Kebo Bule as one of the "magical icon" of The Court of Surakarta. By a qualitative descriptive method, the language and culture of Java in the ethnolinguistic expression of Kebo Bule can be explained as follows.

\section{The background of the Kebo Bule in Surakarta from the Ethnolinguistic Perspective}

Based on the background of Kebo Bule in Surakarta, it can be identified that the Kebo Bule as the dearest cattle to the king reflects a phenomenal properties in the Court of Surakarta, and of course, it is quite complicated to explain and answer its existence. The explanation about Kebo Bule is still confusing and there is no adequate source of information. In addition, to address issues related to the complexity and phenomenality of Kebo Bule, the author provides critical interpretations about the phenomenon of Kebo Bule from the verbal (linguistic) and nonverbal expressions (identified from the historical, cultural, spiritual, practical and political aspect). Verbally, it may be questioned why the expression Kebo Bule are varied in that it is so-called "Slamet Kebo", "Kyai Slamet", and is also closely related to the nightly ritual ceremony of $1^{\text {st }}$ month of Sura (Miksic 2004).

Kraton places various symbols as the royal heirloom performed for a major component in each groups covenant in the $1^{\text {st }}$ 
month of Sura carnival eve. In the carnival eve the royal families covenant would walk together in parade complete traditional clothes beskap 'black clothing', blangkon 'traditional cap', and other typical cloths for men. Meanwhile the women dressed in complete black kebaya clothing with their hairs in a bun. The people whose duty carrying heirlooms are to wear Sumpingan Gajah Oling jasmine floral arrangements placed in the ear. For those who are not in charge of carrying heirlooms, they carry lanterns and torches to illuminate the carnival contingents. Uniquely the covenants were led by Kebo Bule Kyai Slamet which became the center of public attention during the carnival eve.

Physically, Kebo Bule has a different skin color to be compared to most buffalos in the Java Island; it is white and somewhat reddish. According to Javanese people, the analogy is associated with the skin color of the Europeans', wong bule 'bule', because the Javanese people recognized 'the Dutch' Landa (who has colonized them for \pm 350 years). Consequently the buffalo skin color which is like Landa 'Dutch' is understood beyond any type of buffaloes in Java of black and grayish. Differences in the skin color of the buffalo in the life of the Javanese also lead to a perception that the buffalo is unusual and has been linked with things that are not usual anyway. Therefore, the Javanese who inherited the agrarian tradition looked at the buffalo as "the rich king", that is, cattle that can help to produce more livings (to become rich men). Besides, the different skin-colored buffalo is also physically and metaphysically linked to the inner and outer life in the way of solving various existing problems. Consequently the perceptions related to Kebo Bule remains weird because they have been entering cosmomystical and cosmo-magical realms of life. In this case the existence of Kebo Bule is still one important part of the indigenous life in the Sultanate Court of Surakarta especially at the moment of the ceremony at the night of $1^{\text {st }}$ month of Sura (www //: kerajaannusantara.com, November 1, 2014).

Spiritually, one may have perceived Kebo Bule as "guide figure" during the car- nival night of $1^{\text {st }}$ month of Sura. As "Panuntun" (guide figure), because Kebo Bule is understood to have acquired physical characteristics of being strong, large, albino, "patient" and is essentially different from any other buffalos, and it often has a strange behavior in everyday life. The strangeness of it is when it left wild, Kebo Bule doesn't want to damage the people's plants, or eat vegetables at the traditional market. Instead, if the Kebo Bule eats vegetables or foods in the market, the merchants or the sellers would feel good, because it is believed to be pelarisan 'selling demand stimulant', and the farmers would understand that the agricultural results will be abundant. In addition, the strange behavior of Kebo Bule was narrated in the story that in the old time, on a year of wild journey, these buffalos went up to Pekalongan, Wonogiri, Cilacap, Madiun, and the other regions, but on the eve of the ist night of Sura, the Kebo Bule returned back to the Court of Surakarta. This attitude of Kebo Bule was perceived as ready to run the king's spiritual duty. Because of that weird attitude, people living around the Court tend to have weird attitude to Kebo Bule and the relationship with the agrarian life. The non-verbal expression emerged from the behavior of taking tlethong the dung of Kebo Bule many people end up with competing or fighting to get the dung, because it is perceived to be a blessing to pour in their planting fields ${ }^{5}$ (Tuasikal, February 27, 2013).

The existence of Kebo Bule in the eve of $1^{\text {st }}$ Sura Carnival led to the emergence of a cultural phenomenon beyond the teachings of the palace. Kebo Bule Kyai Slamet is a symbol for safety, but the meanings exaggerated by people outside the court, indeed behave exaggeratedly during the carnival. As a special animal, Kebo Bule for some people who hold the belief would believe that Kebo Bule reflect supernatural powers that can bring blessings. Consequently, many people begin to ngalap berkah (seeking blessing) by fighting over all things related to kebo bule, ranging from the rest of the food, drink, jasmine flowers that fell from the necklace, even the faces.

Politically, Kebo Bule is associated 
with the $1^{\text {st }}$ night of Sura month (formerly Hindu culture, Caka, Samsiyah). At the time of Sultan Agung Mataram, the Javanese calendar was setup into a New Year calendar called Hegira (Islamically, Qomariyah). As a result of the calendar changes, the next development, among others, posed a disputing understanding of Kebo Bule as a blessing (in Javanese spiritual) and Kebo Bule of as a "syirik -act of ignorance to God" (in religious understanding). Therefore, Kebo Bule should be understood both politically and spiritually since the Javanese culture is complex and complicated. Politically and culturally within the meaning of Kebo Bule, it is illustrated there was a process of acculturation of culture from other areas of The Surakarta Court.

\section{The Effects of Kebo Bule on the Court of Surakarta from Ethnoliguistic Perspec- tive}

The next question in this research is the extent to which the Kebo Bule influences the lives in the Court of Surakarta. In this case, the answer can be given to the three sensitive issues related to the influence of sacred Kebo Bule in the Court of Surakarta, which include (1) verbal aspect concerning the given name of Kebo Bule, (2) practical expressions on the influence of Kebo Bule, and (3) the spiritual evidences related to the influence of supernatural Kebo Bule in the Court of Surakarta.

In the verbal aspect, Kebo Bule in the Javanese tradition, especially in the court of Surakarta, is traditionally named "Kyai Slamet" and "Kebo Slamet". What is the relationship between the verbal expression of Kebo Bule with "Kyai Slamet" and "Kebo Slamet "? According to the data, it is found that the expression can be interpreted from the core of verbal expression, namely "Kebo, Kyai" and "Bule and Slamet". Ethnolinguistically in the Javanese tradition, especially in the Court of Surakarta, verbal expression correlated with the buffalo's name is understandable in this way. The meaning of "Kebo" equated with the term "Kyai" or vice versa as expressed in "Kebo Slamet" and "Kyai Slamet". As for the perspective of cultural semantics correlates with the Javanese diction to the buffalo's name, it can be criticized from the two possible perceptions of the Javanese environment in the Court of Surakarta. First, the attitude in that tradition means to honor the Kebo Bule which is perceived by its supporters as a media of fortune. The given name "Kyai" refers to its sacredness and role as a social agent "savior" in the life of the surrounding environment.

It can be understood that there are pros and cons with the growing influence of Islam, Hinduism and Buddhism in Java. The two Javanese literatures of Serat Gatholoco and Darmagandhul can be a media to give illustration that there are other parties who have a different perception of the others (in this case is Moslems). The life nuance of language and culture of Javanese are summarized in the expression of the title and content of Serat Gatholoco and Darmagandhul, and the associated perceptions summarized in Kebo Bule can actually be interpreted as something unintentionally happening, either in the context of the life of language and culture or in a political context related to the struggle for influence among the Javanese at that time. The center of hope and motivation is the acquisition of the cultural, spiritual, practical (politics), material as well as geographical territory in Java. In the other interpretation, in order to establish the legitimacy of the king's power it can be reached through weird things, so that people will unable to understand the reasoning (PC. Pitana, August 20, 2016). As a result, up to now the cultural hegemony was still in the palace for those who do not agree with the expression Kebo Bule.

Practical expression of the Kebo Bule influence is particularly seen on its role to serve a duty to be become cucuk lampah at the traditional night ceremony of $1^{\text {st }}$ month of Sura. The chosen cucuk lampah was not human, but the cattle called Kebo Bule. Why should it be Kebo Bule? Because in Javanese perception, especially in the perception held by the Court of Surakarta, Kebo Bule is perceived not as any cattle or buffalo in general, but it is the sacred and most authoritative and respected animal ('pepun- 
den keramat'). According to the Court of Surakarta's courtiers, Kebo Bule is a big male buffalo and a descent of Kebo Bule from the Court of Sultan Agung Mataram Hanyakrakusuma (PC. with Purwasito, August 14, 2016). Thus, the practical duty of Kebo Bule is as a complement to the royal ritual, even today the task remains the same. Although there are changes, however, it is only at the level of accessories and nurturing to adjust the situation (PC. with Haryono, August 20, 2016). In addition, practically the figure of Kebo Bule became part of the tourism site, especially during the evening ritual of $1^{\text {st }}$ month of Sura as well as the other cultural events which are equipped with a Kebo Bule. Many people may consider Kebo Bule as an instrument or media of a ritual, but many could say it as part of the weird practice and tourism, Kebo Bule became cucuk campah, and Kebo Bule as sacred animal whose dung is precious.

The empirical spiritual evidence related to the supernatural influence of Kebo Bule on The Court of Surakarta remains worth questionable. Empirical data that has to do with supernatural power in Kebo Bule and the disaster in the Court of Surakarta is lack of evidence. Some of the occurring events in the Court of Surakarta related to the magical side of Kebo Bule are hard to prove the existence. The powerfulness and sacredness of Kebo Bule was ruined once an incident happened at Kebo Bule named Bagong which died after being hit by a spear of irresponsible people and was thought to be a disaster event for the culture. This unfortunate event leads to disputes in the perceptions of the Javanese people over the years; it weakens the assumption that Kebo Bule really has the magical power (PC. with Sutarjo, August 21, 2016). In addition, if in itself poses a magical power that can be relied upon, why a problem in the Court of Surakarta barrage and until now has not been resolved. The problem over succession has not been finished yet, the problems between the royal family and other cases were still being argued. This fact has given the answer that Kebo Bule with all the embedded perceptions are typically a set of a form of legiti- macy. It provides a way to build a spiritual motivation to overcome physical and mental problems that occurred in the kingdom at the time.

\section{The meaning of Kebo Bule as one of the "magical icon" of The Court of Sura- karta}

Among the constructed meanings summarized in the verbal expression of Kebo Bule ethnolinguistically it can be identified from the cultural meaning, connotative meaning, historical (political) significance and practical significance.

If the Kebo Bule is understood as one of the "magical icon" to the Court of Surakarta, it becomes a physical representation or illustration of something that culturally Java is sacred hence the perception of magic, sacred, unusual buffalo, and the perception of others as interpretative are something that has been built by the ancestors culturally and pragmatically for certain purposes (e.g. legitimacy, motivational building, to frighten the enemy, 'klangenan' being dearest cattle, entertainment'). The intention at least summarized in the framework of legitimacy and authority figure of the king, and surrounding cultural activities. Therefore, to understand the cultural semantics requires interpretation before finally formulate the purpose of verbal expressions reflected on the terms of Kebo Bule, Kyai Slamet or Kebo Slamet. Ethnolinguistically, Kebo Bule is interpreted reddish like "Bule"(Landa 'Dutch'); additionally "Kyai Slamet" was named after its care taker's name who was Kyai Slamet. Kebo Slamet is culturally interpreted buffalo that provides a sense of survivors, pleasure, and entertaining. The perception of slamet 'salvation' can be interpreted from the two perspectives, namely the materialistic side of buffalo which gives a sense of life optimism, because as the rich king produce a living and was delighted to have the buffalo as an investment in the form of animal; the categorically unusual colored buffalo which suggests blessing of its own. However, also mentioned at the end of the description of section (B), that Kebo Bule, Kyai Slamet or "Kebo Slamet "a magical icon" of the Court 
of Surakarta became insignificant anymore in the Javanese practices, especially in the palace along with various events. As a result, the extent to which the role of Kebo Bule as "the miracle icon" to the Court of Kasunanan with reality conditions can be accounted for (PC. with Puger, August 21, 2016; Kompas. com, October 15, 2015). Bearing in such condition, it becomes an important answer and evidence on how are the roles of Kebo Bule as the magical icon of the Javanese Court? On the other hand, in its development after listening to various events in Kasunan, the cultural meaning of verbal expression of Kebo Bule or "Kyai Slamet" viable is now more viable merely an icon to complete the carnival eve of the $1^{\text {st }}$ moth of Sura, both for domestic and foreign tourists.

As for the connotative meaning of verbal expression of Kebo Bule or "Kyai Slamet" or "Kebo Slamet" represent a sense of beyond factual and figuratively expressed meanings to cope with problems in explaining the spiritual belief, thus alternatively has to be explained through symbolic ways. Any option has to be chosen to convey the unspeakable or untold messages summarized in the verbal expressions of Kebo Bule. Javanese communities are identical to symbols as a means of petition or prayer to the Almighty God. It is true that Kebo Bule interpreted as a symbol of salvation, but such symbol is often interpreted by common people as repellent of calamities. Conceptually the repellent of various disasters to survive, but the message may not arrive at an understanding among the general public. People do repellent of calamities in their own way which often does not make sense.

"Kyai Slamet" or "Kebo Slamet" are the epithet was given based on a person who took care of the buffalo, thus it inherited his name. For that, the other party can interpret only limitedly by the context of Javanese culture in its time (PC. with Sutarjo, August 21, 2016. While the historical significance (political) of verbal expressions Kebo Bule or "Kyai Slamet" or "Kebo Slamet" can be interpreted that the emergence of verbal expression of Kebo Bule or "Kyai Slamet" or "Kebo
Slamet" cannot be separated from the history (political ). As mentioned before that the other name for Kebo Bule is Kyai Slamet. Historically, the name cannot be separated from the cultural semantics of Java. Kyai 'a man of esteemed, respected, has extensive knowledge (if female called Nyi)'and Slamet means 'salvation'.

The story of Kebo Bule or "Kyai Slamet" or "Kebo Slamet" has begun at the reign of Pakubuwana II in Kartasura, the buffalo was a gift from the Duke of Ponorogo, and because of its virile form, handsome and unique buffalo became klangenan 'the dearest cattle' to the king (kesolo.com, December 6, 2014). Ethnolinguistically, it is questionable why the Duke of Ponorogo gave up albino buffalo as a gift to Pakubuwana II in Kartasura (PC. with Sutarjo, August 21, 2016). It can be interpreted as physically the buffalo was indeed interesting, unique, and unusual type of buffalo, and metaphysically is probably a repellent completeness of custody when The Court of Kartasura was attacked by Chinese people on the orders of VOC. It could also be the provision of "Kebo Bule 'as an indirect criticism for the defeat of King Kartasura who had fled to Ponorogo for hiding. It was implied in Kebo Bule provide guidance, amulets, magic, sacred, followed, even more than just a perception of Javanese people.

\section{CONCLUSION}

Based on the background of Kebo Bule in Surakarta, it can be identified that the Kebo Bule as cattle which gained its special position in the Court of Surakarta. The existence of Kebo Bule in the eve of $1^{\text {st }}$ Sura Carnival led to the emergence of a cultural phenomenon beyond the teachings of the palace. Kebo Bule Kyai Slamet is a symbol for safety, but the meanings exaggerated by people outside the court, indeed behave exaggeratedly during the carnival. Besides the spirituality and cultural phenomena of Kebo Bule at least corresponding to three sensitive issues, namely (1) the expression of verbal name for Kebo Bule, (2) the practical expression concerning the influence of Kebo Bule, and (3) evidence of spiritual effects related to the 
magic of Kebo Bule in the Court of Surakarta. The meaning of Kebo Bule as one of the magical icons to the Court of Surakarta from the ethnolinguistic perspective identifiable through the cultural meaning, connotative meaning, historical significance (political) and practical significance.

\section{REFERENCES}

Abdullah, W., 2013. "Kearifan Lokal dalam Bahasa dan Budaya Jawa Masyarakat Nelayan di Pesisir Selatan Kebumen (Kajian Etnolinguistik)", Disertasi, Universitas Sebelas Maret, Surakarta.

Ahimsa-Putra, H.S., 2003. Etnosains: Mengungkap Pengetahuaan Masyarakat Pedesaan. Dinamika Pedesaan dan Kawasan. 4(4), pp.34-35.

Ahimsa-Putra, S.S., 2007. Ilmuwan Budaya dan Revitalisasi Kearifan Lokal. Tantangan Teoretis dan Metodologis". Pidato Ilmiah Dies Natalis FIB UGM ke 62. Gadjah Mada University Press, Yogyakarta.

Childs, B. and Mallinson, C., 2006. The significance of lexical items in the construction of ethnolinguistic identity: A case study of adolescent spoken and online language. American Speech, 81(1), pp.3-30.

Dove, M.R., 1985. Peranan Kebudayaan Tradisional Indonesia dalam Modernisasi. Tiara Wacana, Yogyakarta

Foley, W.A., 1997. Anthropological Linguistics an Introduction. Blackwell Publishers, University of Sydney.

Geertz, C., l981. Abangan, Santri, Priyayi dalam Masyarakat Jawa. Pustaka Jaya, Jakarta.

Kasunanan Surakarta Hadiningrat. 2016. Kebo Bule: Binatang Peliharaan, Kerajaan Nusantara. Retrieved August 19, 2016 (http://www.kerajaannusantara.com/id/-surakarta-hadiningrat/ peliharaan).

Kesolo.com. (December 6, 2014). "Kebo Bule Kyai Slamet, Pusaka Hidup Keraton Surakarta". [Website Post]. Retrieved from: http://kesolo. com/kebo-bule-kyai-slamet-pusaka-hidupkeraton-surakarta/

Kim, H.S., Sherman, D.K. and Taylor, S.E., 2008. Culture and social support. American Psychologist, 63(6), p.518.

Koentjaraningrat. 1967. Beberapa Pokok Antropologi Sosial. Dian Rakyat, Jakarta.

Koentjaraningrat. 1971. Manusia dan Kebudayaan di Indonesia. Djambatan, Jakarta.

Koentjaraningrat. 1977. Metode-metode Penelitian Masyarakat. Gramedia, Jakarta.

Kompas.com. (October 15, 2015). "Inilah Makna Kebo Bule Kyai Slamet Bagi Orang Jawa”. Retrieved from: http://regional.kompas.com/ $\mathrm{read} / 2015 / 10 / 15 / 21590361 /$ Inilah.Makna.Kebo. Bule.Kyai.Slamet.Bagi.Orang.Jawa

Levisen, C., 2015. Scandinavian semantics and the hu- man body: an ethnolinguistic study in diversity and change. Language Sciences, 49, pp.51-66.

Liebkind, K., 2010. 13. The Swedish-speaking Finns: A case study of ethnolinguistic identity. Social identity and intergroup relations, p.367.

Majid, A. and Levinson, S.C., 2011. The senses in language and culture. The Senses and Society, 6(1), pp.5-18.

Medubi, O., 2010. A cross-cultural study of silence in Nigeria-an ethnolinguistic approach. Journal of Multicultural Discourses, 5(1), pp.27-44.

Miksic, J.N., 2004. The Court of Surakarta. BAB Publishing Indonesia, Surakarta.

Mulder, N., l984. Kebatinan Hidup Sehari-hari Orang Jawa. Gramedia, Jakarta

Perales, H.R., Benz, B.F. and Brush, S.B., 2005. Maize diversity and ethnolinguistic diversity in Chiapas, Mexico. Proceedings of the National Academy of Sciences of the United States of America, 102(3), pp.949-954.

Purwasito, A., 2015. Kebo Bule in Kraton Surakarta: Kebo Bule itu Sang Panuntun”. Retrieved. July 10, 2015 (http://tempatwisatadaerah.blogspot. co.id-/2015/10/kirab-kebo-bule-malam1-suro-di-solo.

Raden Mas Said. 2015. Kesaktian Kebo Slamet Kraton Surakarta”. Retrieved December 10, 2015 (http://tempatwisatadaerah.blogspot. co.id/2015/10/ kirab-kebo-bule-malam-1-surodi-solo)

Spradley, J.P. 1997. Metode Etnografi [Trans. Misbah Zulfa Alizabeth]. Tiara Wacana, Yogyakarta.

Sudaryanto. 1993. Metode penelitian Linguistik. Duta Wacana University Press, Yogyakarta.

Sutopo, H.B., 2006. Metode Penelitian Kualitatif. Universitas Sebelas Maret Press, Surakarta.

Tanaamah, A.R. and Wenas, M.B., 2014. Javanese Culture Digitalization in a Knowledge Management Framework At Kasunanan Surakarta Palace. International Journal of Computer Science Issues (IJCSI), 11(3), p.125.

Thorne, S.L. and Payne, J.S., 2005. Evolutionary trajectories, Internetmediated expression, and language education. Calico Journal, pp.371397.

Toto. 2015. "Kebo Bule". Retrieved February 10, ,2015 (http://tempat-wisatadaerah.blogspot. co.id/2015/10/kirab-kebo-bule-malam-1-surodi-solo).

Tuasikal. 2013. "Ritual Pesugihan dan Ingin Kaya Mendadak". Retrieved February 27, 2013(https:// rumaysho.com/3195-ritual-pesugihan-daningin-kaya-mendadak-7.html)

Wikipedia. 2015. "Mahesa/Kebo/Lembi Anabrang". Retrieved May 5, 2013 (https://ms.wikipedia. org/wiki/Mahesa/Kebo/Lembu_Anabrang)

Yosodipuro. 2015. "Kebo Bule” Hadiah Bupati Ponorogo kepada Paku Buwana II. Retrieved 2015, August 10, 2015 (http://tempatwisatadaerah-. blogspot.co.id-/2015/10/kirab-kebo-bulemalam-1-suro-di-solo ) 
List of Informants:

- Personal communication with Puger, (August 21, 2016) at Sasono, the Court of Kasunanan Surakarta.

- Personal communication with Pitana (lecturer at postgraduate magister and doctoral program of cultural studies, UNS, 48 years old) August 20, 2016

- Personal communication with Purwasito (FISIPOL UNS, lecturer at postgraduate magister and doctoral program of cultural studies, UNS, 62 years old), August 14, 2016

- Personal communication with Haryono (Anthropologist, lecturer at UNS, 59 years old), August 20, 2016

- Personal communication with Sutarjo (56 years old), August 21, 2016

Notes:

\section{(Endnotes)}

1 Including to determine the place chosen for the displacement of Kartasura to Surakarta palace following the cessation of Kebo Bule which runs eastward (quoted from various sources)
2 Born in Kotagede in 1593, the surname was Raden Mas Jatmika or RM stimuli. The $3^{\text {rd }}$ King Mataram (1613-1645). Son of King Hanyakrawati, the $2^{\text {nd }}$ king of Mataram, his mother was Ratu Mas Adi Dyah Banawati (daughter of Prince Banawa from Pajang). Other versions mentioned that Sultan Agung, a son of the Prince Purbaya (brother of King Hanykrawati. It is said that when he was just a baby, he was exchanged with son of Ratu Adi Dyah Banawati. The minor version of this, the Sultan Agung married 2, namely Ratu Kulon of Putri Sultan Cirebon had a son named Prince Alit, was wife of another daughter of the Duke of Batang (grandson of the guardian Martani) (biografi. blogspot.com, retrieved November 12, 2014).

3 Whatever the Europeans, they are acknowledged to the Javanese as Landa 'Dutchmen'

4 Can be taken from Jarwa dhosok 'randomly produced words' as the word Maesa' refers to a buffalo' associated with the word Mahaesa (Wikipedia, 2013) meaning 'the ruling, influential' (because of a magical power).

5 Despite not all Javanese believe understanding and ways like that. 